https://doi.org/10.24101/logos.2016.20

Gauta 20161012

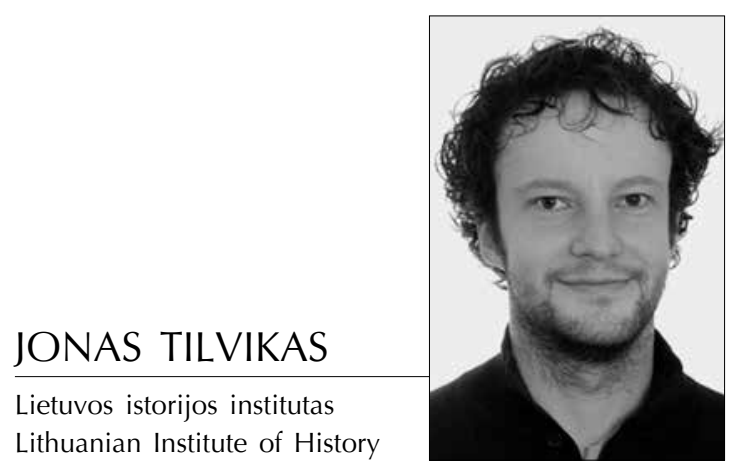

\title{
TARP RELIGINIŲ, KULTŪRINIŲ, SOCIALINIŲ PRIEŠPRIEŠŲ: LIETUVININKŲ LIAUDIES MEDICINA XIX-XX A. PIRMOJE PUSĖJE
}

\author{
Between Religious, Cultural and Social Contradictions: \\ The Traditional Medicine of Lithuania Minor from \\ the 19th till Beginning of the 20th Century
}

SUMMARY

This article analyzes the traditional medicine of Lithuania Minor from the 19th till the beginning of the 20th century. This research describes the circumstances of traditional medicine in Lithuania Minor, its religious, cultural and social contradictions. The sources of this research are the ethnographic texts of educated people of Lithuania Minor: Karlas Kapeleris, Vilius Kalvaitis, Kristupas Jurkšaitis, Ansas Bruožis, Jonas Skvirblys. In the works of these authors the concept of traditional medicine is filled with various elements of magic. But at the same time are obvious the Christian perspectives which condemn the magic methods of healing and the people that practice such methods. Despite the religious criticism of such methods, they were popular in Lithuania Minor at those times. They solved not only health but also social and cultural problems. Traditional medicine marked a distinction between religious views and two different ethnic groups: Lithuanians and Germans. The social aspects, such as family relations and community building, were important for the existence of traditional medicine. The economic situation at that time also supported the practice of traditional medicine.

\section{SANTRAUKA}

Straipsnyje analizuojama XIX-XX a. pirmosios pusės lietuvininkų liaudies medicina. Šiuo tyrimu siekiama atskleisti lietuvininkų liaudies medicinos gyvavimo aplinkybes tarp religinių, kultūrinių ir socialinių priešpriešų. Tyrimo šaltinis - Mažosios Lietuvos šviesuolių Karlo Kapelerio, Viliaus Kalvaičio, Kristupo Jurkšaičio, Anso Bruožio, Jono Skvirblio etnografiniai tekstai. Šių autorių tekstuose liaudies medicina persmelkta

RAKTAŽODŽIAI: lietuvininkai, liaudies medicina, religinės, kultūrinės, socialinės priešpriešos.

KEY WORDS: people of Lithuania Minor, traditional medicine, religious, cultural and social contradictions. 
maginių elementų. Tačiau čia pat išryškejja dalies lietuvininkų kriščioniškosios pažiūros, smerkiančios magija paremtus gydymo būdus ir tokiais būdais besinaudojančius žmones. Nepaisant bažnytinio pasmerkimo, liaudies medicina buvo gaji ir svarbi to meto lietuvininkams, nes sprendè ne tik jų sveikatos klausimus, bet ir socialines bei kultūrines problemas. Liaudies medicina žymėjo takoskyrą tarp skirtingų religinių pozicijų bei etninių grupių - lietuvių ir vokiečių. Svarbūs liaudies medicinos gyvavimui buvo to meto socialiniai aspektai: šeimos santykiai, bendruomeniniai ryšiai. Liaudies medicinos gyvavimą palaikè ir tuometinè ekonominè situacija.

\section{IVADAS}

XIX a. pabaigoje-XX a. pradžioje pradèjus tyrinèti liaudies mediciną, buvo sukaupta nemažai tekstų apie šią liaudies kultūros sritị. Tuo metu pradèti publikuoti darbai, perteikiantys liaudies medicinos žinias, tai dr. Jono Basanavičiaus ${ }^{1}$, Gabrielès Petkevičaitès-Bitės² kūriniai. Kazio Griniaus ir folkloro komisijos nariu sudarytoje metodineje priemonèje Trumpa folkloro dalykams rinkti programa idètas klausimynas Žmoniu medicina ${ }^{3}$. Dr. J. Basanavičiaus įskelta kibirkštis, raginimas rinkti medžiagą tautiškai vaistininkystei buvo pasiekusi ir Mažają Lietuvą. Su dr. J. Basanavičiumi tiesiogiai bendradarbiavo bent trys autoriai iš Mažosios Lietuvos: Vilius Kalvaitis (1848-1914)5 ${ }^{5}$, Kristupas Jurkšaitis (1852-1915)6, Ansas Bruožis (1876-1928) 7 . Jie, atsiliepdami i tautinio atgimimo patriarcho raginima, rinko etnografinę medžiagą neaplenkdami ir medicinos temos. Žiniu apie lietuvininkų liaudies mediciną pateikiama ir kitų Mažosios Lietuvos šviesuolių - Karlo Kapelerio (Carl Cappeller) (18401925) ${ }^{8}$, Jono Skvirblio (1902-1990) ${ }^{9}$ - darbuose. Kaip matyti iš gimimo ir mirties datu, beveik visi autoriai yra amžininkai, gyvenę XIX a. antrojoje puseje-XX a. pradžioje. Išimtis - J. Skvirblys, gimęs XX a. pradžioje ir miręs to paties amžiaus pabaigoje. Iš aptariamų autorių pirmas pa- sirodė K. Kapelerio darbas Kaip senieji lietuvininkai gyveno, parašytas 1876 m., išspausdintas $1904 \mathrm{~m} \cdot{ }^{10} \mathrm{~A}$. Bruožio tekstai Jono Balio rūpesčiu publikuoti $1937 \mathrm{~m}$. Tautosakos darbuose, 3-iame tome Iš Mažosios Lietuvos tautosakos ${ }^{11}$. K. Jurkšaičio ir V. Kalvaičio tekstai paskelbti $2004 \mathrm{~m}$. Juodojoje knygoje ${ }^{12}$. J. Skvirblio publikacijos Kas tos raganos ir apžavėtojai ${ }^{13}$ ir Mažosios Lietuvos kaimo gydytojai ${ }^{14}$ paskelbtos 1985 m. Lietuvos pajūryje ir 1988 m. Čikagoje, dar kartą perspausdintos $2003 \mathrm{~m}$. knygoje Mažosios Lietuvos garbinga praeitis, liüdna dabartis ir neaiški ateitis ${ }^{15}$.

Nors kai kurie tekstai parašyti daugiau nei prieš šimtą metu, jie iki šiol nèra sulaukę išskirtinio liaudies medicinos tyrëjų dėmesio. Pirmieji etnologo susidomejimo sulaukè A. Bruožio tekstai. J. Balys pateikè kuklu šio autoriaus tekstu apibūdinima, atkreipdamas dèmesí, kad „Šis klaipédiečių burtų-prietaru ir liaudies medicinos rinkinys yra įdomus ne tik tautosakininkui, bet ir kalbininkui, nes čia randama daug retų ir gražių lietuvišku žodžių bei išsireiškimų “16. Jo nuomone, kalbininkų uždavinys bus atskirti, kurie yra tikri liaudies žodžiai, o kurie galbūt A. Bruožio naujadarai ${ }^{17}$. K. Kapelerio pateikiami liaudies medicinos duomenys turbūt vieninteli kartą aptarti Janinos Janavičienès pranešime „Senujų lietuvinin- 
kų liaudies medicina"18. Autorè K. Kapelerio pateiktas liaudies medicinos žinias lygino su Oto Glagau, Kristijono Donelaičio, Vydūno ir kitų autorių tekstais ${ }^{19}$. Leonardas Sauka Juodosios knygos ivade skiria keletą pastraipų V. Kalvaičio ir K. Jurkšaičio tekstams ${ }^{20}$. L. Sauka, remdamasis V. Kalvaičio Dienknygomis ir jo laišku vyskupui Friedmanui, atkreipia dèmesi i sudètingas užrašinėjimo aplinkybes - vokiečių nutautinimo politiką ir konfesinius procesus $^{21}$. Paminimi K. Jurkšaičio tik biografijos faktai ${ }^{22}$.

Liaudies medicinos tyrimų pradininko J. Basanavičiaus lūkestis, jog liaudies medicinos medžiaga padès ateities Lietuvos mokslui, pasiteisino tik iš dalies. Darbai publikuoti, bet gilesnio analitinio žvilgsnio nèra sulaukę. Vis dèlto šių darbų pamiršti nederètų. Tai istoriniai šaltiniai, kuriais galima pasinaudoti atliekant šiandieninius liaudies medicinos tyrimus. Nekalbant apie juos, šiandienos darbai neišlaiko tęstinumo ir tarsi kiekvieną kartą pradedami iš naujo. Tačiau norint palyginti istorinius duomenis su šiandienos rezultatais kyla metodologinių problemų. Aptariami šaltiniai parengti prieš šimtą metu, o dar ir šiandien Lietuvoje nèra nusistovèjusios liaudies medicinos tyrimo kryptys, formuojasi tyrimo metodologija ${ }^{23}$. Istorinių šaltinių sugretinimo problemos kyla iš nevienodo požiūrio ị tyrimo objektą ir skirtingu tyrimo prieigų. Todèl šiandien atliekamiems liaudies medicinos tyrimams svarbu išryškinti aktualius aspektus.

Šiuo tyrimu bus siekiama atskleisti lietuvininkų liaudies mediciną tarp religinių, kultūrinių ir socialinių priešpriešų XIX a. ir XX a. pirmoje pusëje remiantis K. Kapelerio, V. Kalvaičio, K. Jurkšai- čio, A. Bruožio, J. Skvirblio etnografiniais tekstais.

Siekiant šio tikslo bus išryškintos religinès nuostatos, apibūdinti lietuvininkų liaudies medicinos kultūriniai bruožai, aptarti lietuvininkų liaudies mediciną formavę etniniai, ekonominiai, socialiniai veiksniai.

Tyrimui naudojamų tekstų duomenys lyginami tarpusavyje. Autorių požiūriui išryškinti remiamasi papildomais biografiniais tekstais ir publikavusių autoriu vertinimais. Esama keblumų norint apibrèžti tyrime naudojamų naratyvų laiko ribas. V. Kalvaičio, K. Jurkšaičio, A. Bruožio publikacijose nurodoma, kad pasakojimai užrašyti XIX a. pabaigoje. J. Skvirblio tekstų parašymo data neaiški, tikètina, kad sutampa su publikavimo datomis. Tačiau autoriaus pasakojimų laikas artimas V. Kalvaičio, K. Jurkšaičio ir A. Bruožio laikui. J. Skvirblys aprašo ivykius, nutikusius jo vaikysteje $X X$ a. pradžioje (autorius gimęs 1902 m.). Autorius perpasakoja ir savo tèvo pasakojimus, kurio prisiminimai turètų siekti XIX a. antrą pusę. Teksto ir ivykių chronologinès ribos nesutampa ir su K. Kapelerio darbu. Jis aprašo daugiausia savo tèvo prisiminimus, kurie siekia XIX a. pirmą pusę. Ivykių laiko ribos ne visada aiškios ir kitų autorių - V. Kalvaičio, K. Jurkšaičio, A. Bruožio - pasakojimuose. Nors tekstai užrašyti XIX a. antroje puseje, vis dèlto kai kuriais atvejais kalbama apie būtajij laiką arba perteikiami pasakojimai, kurie galètų būti pateikèju prisiminimai. O tai jau taip pat būtú XIX a. vidurys arba net pirma pusè. Taigi autorių darbuose aprašomo laiko ribos apima apytiksliai nuo XIX a. pirmos pusès iki XX a. pirmos pusès. 


\title{
LIETUVININKŲ LIAUDIES MEDICINA TARP RELIGINIŲ PRIEŠTARŲ
}

\author{
...šiandien sviete geriau yra, nes jau nevierijam \\ ir nedarom tokius niekniekius ir tokias durnystes kaip mūsų sentėviai. ${ }^{24}$
}

Autorių naratyvuose atsispindi jų pozicija bei lietuvininkų liaudies medicinos ir elgesio gydantis vertinimai. Šiandienos metodologiniu požiūriu autorių pateikiami tiriamojo objekto vertinimai, juolab iterpiami i etnografinius pasakojimus, nèra korektiški. Vis dèlto iš didelès laiko perspektyvos autoriu pozicija tampa idomi. Net nedidelès užuominos, paryškintos detalès ar dedami akcentai atskleidžia gilias kultūrines prieštaras, kurių nematyti tekstuose, kuriuose aptariami tik ligu gydymai. Viena ryškiausių priešpriešų lietuvininkų liaudies medicinoje - krikščionių bažnyčios ir pagonybès reliktų sandūra. Turbūt ryškiausiai ji išreikšta K. Kapelerio tekste. Nors liaudies medicina K. Kapelerio knygelëje Kaip senëji Lètuvininkai gyveno aprašyta kukliai (vos po vieną ar po kelis sakinukus), tačiau užuominos labai iškalbingos ir informatyvios. Tekstai liaudies medicinos tema pateikiami skyriuje, kuri autorius pradeda žodžiais:

Taip gyveno ir mirè senieji lietuvininkai ir aš misliju, kad vienam daikte šiandien sviete geriau yra; nes jau nevierijam ir nedarom tokius niekniekius ir tokias durnystes kaip musu senteviai. ${ }^{25}$

Čia aiškiai matyti autoriaus nuomonè apie toliau skyriuje pateikiamus lietuvininkų tikejjimus ir liaudies medicinos faktus. Autorius nurodo ne vieną niekniekių pavyzdị: kalendorinių švenčių papročius, tikèjimus, prietarus, mitologines sakmes. Tarp šių pavyzdžių esama tikejjimų, iliustruojančių lietuvininkų požiūrị i gydymą. Iškalbingiausia K. Kapelerio pastraipa apie lietuvininku gydymąsi yra ši:

Kad vèns apasirgo, daktaro nebrūkavo, jie ligoni glostė ir rūkino švęstoms žolèmis, tankiai ir apžadejjo, ypačiai dantų arba krūtinès skaudèjimą. Daugiausiai kokia sena moteriškè tą darbą padarè, nès buvo gerai apdovanota, kad ligonis sveiko, ale kad numirè, tai ji nieko negavo... ${ }^{26}$

Pastraipoje pateikiama nemažai įdomių ir svarbių dalykų liaudies medicinos tema. Iš jos sužinome apie gydymosi būdus ir nuostatas, apie gydančius asmenis bei socialinius, ekonominius santykius tarp gydančių ir besigydančiu lietuvininkų. K. Kapeleris, nurodęs, kad lietuvininkai ligoni brauko, smilko, apžada, toliau rašo, kad tai kvailystè, pagonybès liekanos. Autorius ne tik šiuos gydymo būdus, bet ir visus tikejjimus, susijusius su sveikata, vertina kritiškai: „sentèviai visokias durnystes ir niekniekius vierijo", ir čia pat priduria, kad jo laikais tais burtais nebeverija. Kiekvieną aprašymą K. Kapeleris baigia arba pradeda pastabomis: „Ar tai nebuvo durnystė?" 27 ; „Ale ne visi tai vierijo. “28; "Tai buvo pagoniškas būdas. “29; , "Šiandien išmoningi žmonès tai nevierija, ir tai gerai. "30 Autorius nesigilina, ar tai gydymo priemonès, ar paprotys, jis išvien nuvertina visus dalykus, susijusius su faktais, prieštaraujančiais krikščioniškai pozicijai. Tačiau autorius nesigilina, kuo negeri sentèviu tikejjimai ir kodèl gerai, kad taip nebetikima. Pakanka to, kad tokie gydymai ir tikejjimai yra pagonybès liekana. 
Tarsi atliepdamas i K. Kapelerio iškeltą sentèvių tikejjimo problema, savo nuomonę išsako ir K. Jurkšaitis. Autorius Pryvierose ${ }^{31}$ pateikia ịvairių gyvenimišku situacijų, liudijimu, tikèjimų pavyzdžių iš viso trisdešimt tris tekstus. Tai pranašysčių, pranašingų sapnų, ugnies tramdymo, susirgimu, gydymu atvejai. Itin daug dèmesio autorius skiria sapnams ir apskritai su miegu susijusiems reiškiniams aprašyti - tokių tekstų septyni. Liaudies medicinos tekstai nėra sudèti i atskirą pogrupi. Jie išsibarstę visame skyriuje. Autorius pateikia keturis tekstus apie pasiutligès ir du apie išgąsties gydymą $^{32}$. K. Jurkšaitis atkreipia dèmesi i grybuku arba činčibuku vartojima, tai esa kūnui labai sveika ir amžia prailgina ${ }^{33}$. Autoriaus pateiktuose tekstuose matyti, kad privieroms autorius priskiria gydymo būdus, kuriuos šiandien vadiname maginiais. Taip pat K. Jurkšaitis linkęs aprašyti psichinio pobūdžio ligas, kaip išgass$t i^{34}$ ar ménesio ligq $q^{35}$. Vienas iddomiausiu autoriaus tekstų liaudies medicinos tema-Smilkymai ${ }^{36}$. Šis tekstas aktualus ne tik išsamiu smilkymo aprašymu - čia atsispindi autoriaus nuomonè apie smilkymą, o kartu ir apie lietuvininkų liaudies mediciną. Ypač šis tekstas iddomus lyginant ji su kitais autoriaus tekstais Apie žinystę ir dyonus darbus ${ }^{37}$ bei Žinystè ir dyoni darbai ${ }^{38}$. Autorius šiuose tekstuose svarsto apie tikejjimo ir žinojimo kategorijas. K. Jurkšaitis i pagonybės laikus žvelgia geranoriškiau nei K. Kapeleris. Jis siekia atskirti žinyste, kaip derama, paveldètą ypatingą žinojima, nuo žynystès - siekimo pakenkti arba tikslo siekimo smerktinomis priemonėmis. Žinystę autorius sieja su žinojimu - „paslèptu daiktų ir tų vartojims visiesm ant gero, norint ir paslèptinè pati neišreiškiama“39. Žynyste, arba žyniavimas, siejama „su žmogaus noru per piktas dvasias arba pašaukimo pono Dievo vardo, arba pakeravimus daugiausiai, ko pikto provyti prieš Aukščiausiojo norą ir valią" ${ }^{\prime 40}$. Iš K. Jurkšaičio apibrèžimu matyti, kad žinystès ir žynystés ryškiausias skirtumas tikslas, kurio siekiama, t. y. gero ar blogo. Kitas ryškus skirtumas - kokios priemonès naudojamos tikslui pasiekti. Jis apgailestauja, kad dabar „krikščioniškame čèse tie abu dalykai yra sumetami iz vieną puodą" ${ }^{\prime 41}$. Autorius bando atrasti senosios ir krikščioniškosios kultūros sąlytį, kitaip tariant, galima ižzvelgti norą užglaistyti liaudiškosios bei oficialiosios (dominuojančios) pasaulèžiūros sankirtas. Praktinis bandymas atskirti pelus nuo grūdų yra autoriaus tekstas apie smilkymus ${ }^{42}$. Čia autorius nurodo smilkymo variantiškumus: esą vieniems atrodè veiksmingiau smilkyti vienokia priemone, kitiems - kitokia ir pan. K. Jurkšaitis aiškina, kad kiekviena liga turi turèti atitinkamą smilkini, ir ragina nemanyti ,būk bile dūmai smilkymui jau tinką"43. Neaišku, ar toki komentarą autorius yra girdèjęs iš pačių lietuvininkų, ar tai jo paties iž̌valgos. K. Jurkšaitis išsiduoda, kad kai kuriuos smilkymo variantus taip pat laiko netinkamais ar nepriimtinais: „Manęs dèl - ir katès šūdu ar rupūže ${ }^{\text {"44; }}$ „Kiti tur pryviera, būk pasmilkymas mačyjančiu būdu tik ant kapinių tegalįs nusiduoti, o tai dar ypatiškoj adynoj. Ale taip tik tedaro senos bobos..." ${ }^{45}$

Daug daugiau ir ivvairesnių liaudies medicinos faktų nei jau paminèti autoriai pateikia V. Kalvaitis. Autoriaus užrašyti 
157 pasakojimai - tikèjimų, prietarų, sakmių, liaudies medicinos pavyzdžiai, autoriaus laiškas vyskupui. Tekstai padalinti i tris skyrius: pirmas - „Pažiūrai“"46, antras - „Burtai. Medicina“47 ir trečias „Laiškas“48. Antrojoje dalyje („Burtai. Medicina“) tekstai nuo 59 iki 82 - ligu gydymo aprašymai. Kituose šios dalies tekstuose autorius ne tiek aprašinèja receptūras, kiek apibūdina îvairias su gydymu susijusias situacijas. Liaudies medicinos žinios aprašomos greta tikejjimų, sapnų ir pranašysčių. Autoriaus tekstuose minimi gydymo būdai taikant įvairias priemones: augalines, gyvūnines, chirurgines, pasitelkiami ir burtai. V. Kalvaitis pateikia kelioliką ligu ir aprašus joms gydyti: akmenligei, derdervinei, drustekiui, nuplikimui, džiovai, plaučligei, karpom, krauligei, kirmèlei piršte, mènesligei, votims, věžligei. Iš jo tekstų nemažai sužinome apie įvairius tiesiogiai ir netiesiogiai gydyme dalyvavusius žmones. V. Kalvaitis pasakoja apie išskirtinių gebejjimų turinčius žmones, kurie vienaip ar kitaip buvo susiję su lietuvininkų sveikata. Pavyzdžiui, autorius mini asmenis, galejusius veikti žmonių sveikata, - prarakus, angiu sušauktojus, apžadètojus. Prarakai numatydavo kitų gyvenimo izvykius, nuspėdavo artëjančią mirti, taip pat mini situacijas, kai būdavo nuspejjama ligos eiga - ar ligonis pasveiks, ar mirs ${ }^{49}$. Angiu sušauktojas galèjo išgydyti nuo gyvatès igèlimo ${ }^{50}$. Minimi ir tiesiogiai lietuvininkų sveikata besirūpinę asmenys: pribuvejjos, liekoriai, daktaras.

V. Kalvaitis nèra linkęs kritikuoti liaudies medicinos. Jis atviresnis lietuvininku tikejjimams ir nelaiko ju pagonybès liekanomis. Autorius žengia dar toliau nei K. Jurkšaitis ir laiške vyskupui svars- to apie dvasinio bei materialaus pasaulio pažinimą ${ }^{51}$. Jis siekia pagrįsti dvasingumą tikèjimą susitikimu su dvasiniu pasauliu ir oponuoja mokslininkams, matantiems tik materialu pasauli. Autorius pakartoja, perpasakoja ivvykius, išdèstytus atskiruose tekstuose, liudijančius anapusinio, dvasinio pasaulio egzistavimą. Šiuos pasakojimus derina su Šventojo Rašto citatomis bandydamas rasti sąsajų tarp lietuvininkų dvasinès patirties ir Bažnyčios mokymo.

Savo nuomonès bei vertinimu išsakyti nevengia ir J. Skvirblys. Publikacijose Kas tos raganos ir apžavėtoja ${ }^{52}$ bei Mažosios Lietuvos kaimo gydytojai ${ }^{53}$ autorius prisimena savo gimtojo kaimo ivvykius, kuriuose jis yra dalyvavęs arba pats stebèjęs. Juos dar papildo šeimos narių pasakojimais. J. Skvirblys tuo pačiu metu yra ir ivvykių dalyvis, ir stebėtojas iš šalies. Abi šios pozicijos autoriaus tekste glaudžiai susipina. Autorius ne tik apibūdina situacija, bet ir ją vertina. Vaikystès patirtis autorius analizuoja žvelgdamas iš didelio laiko nuotolio ir remdamasis susiformavusiomis nuostatomis. Abiejuose tekstuose pasakojimai ir faktai derinami taip, kad atskleistu autoriaus pozicija kurią jis laiko teisinga. I savo kaimo žmonių mediciną J. Skvirblys žvelgia nevienareikšmiškai. Tekstuose jaučiamas itin ryškus noras apsvarstyti liaudies medicinos veiksmingumą. Abu J. Skvirblio tekstai skirti įvertinti lietuvininkų tikejjimus, liaudies medicinos priemones bei juos taikiusius asmenis. Dèl gydymo žolėmis ir toki gydymą taikiusios moters autorius abejonių neišsako, nurodo, kad moteriškès vaistai apsaugodavo nuo pavojingos ligos (pasiutligès). Kaip argumentą autorius aprašo îvykį, 
kai malūninko sūnus, aprietas pasiutusio šuns, nesikreipe pagalbos i̇ netoliese gyvenusią liaudies gydytoją ir ligos paveiktas užsimuše ${ }^{54}$. Pasakojime parodoma, kad savaime ši liga nepraeina. Svarbu pažymèti, kad autorius nepateikia pasakojimo, kuriuo pagrisstų moters, gydžiusios žolèmis, gydymo veiksmingumą. J. Skvirblys pasitiki ne visais liaudies medicinos sèkmès atvejais. Jis perpasakoja savo tèvo pasakotą istorija, kaip šio tèvui skaudèjo dantį. Tẻvas išsiuntęs sūnų pas bobutę vaistų. Tačiau vaikas iki bobutès nenuejjo ir vaistų neparnešè. Tẻvo danties skausmą numalšino padavęs vandens iš balos su alksnio šakelèm, "vaistus" i̇teikęs lyg būtu juos iš bobutès parnešęs. Tẻvas vaistus išgèręs ir užmigęs, o kitą dieną skausmo nebebuvę̨ ${ }^{55}$. Pasakojimas tarsi demaskuoja liaudišką gydymą ir pateikia placebo pavyzdi. Kitu atveju J. Skvirblys pasakoja apie paties išsigydytą liga, tačiau išgijimo paaiškinti negalįs ${ }^{56}$. Autorius samprotauja, kad sunku pasakyti, nuo ko pasveiko senelis ir nuo ko pasveiko jis pats. Taip pat autorius mano, kad abiem atvejais pasveikimas būtu priskirtas gydžiusioms bobutèms, kurios minètuose gydymuose tiesiogiai nedalyvavo. Remdamasis savo patirtimi, savo tèvo, senelio ir kitu lietuvininku pasakojimais, J. Skirblys daro išvada, kad senovëje būta keistenybių, pavyzdžiui, bobutè, galejjusi apsaugoti nuo pasiutligès pasekmių, bet būta ir tokiu, kurie tik pinigus išviliodavo ${ }^{57}$.

Iš tekstų matyti, kad autorius kritiškiausiai vertina pasitikejjimą asmenimis ir gydymo būdais, kuriuos vadiname maginiais bei kuriems sunku rasti racionalų paaiškinimą. Autorius abejoja tokiomis gydytojų rūšimis kaip apskaityto- jai, apžavėtojai, sakytojai. Pasakodamas apie tokius žmones, autorius tiesioginès kritikos jiems lyg ir neišsako, tačiau pamini dviprasmiškas situacijas, susijusias su šiais asmenimis. Autorius atkreipia dèmesi, kad apskaitytojos "gydydavo" visokias pagydomas ir nepagydomas ligas, užkrečiamas ar neužkrečiamas, ir daugelis žmonių mirdavo nepagiję․ $e^{58}$. Autorius iškelia ir pasipelnymo galimybę prisidengiant gydymu. J. Skvirblys atvirai apgailestauja dèl burtu praktikavimo ir tikẻjimo įvairiais magiškais dalykais. Straipsnyje Kas tos raganos ir apžavetojai autorius tiesiai išsako savo religines pažiūras ir nuostatas dèl maginių priemonių naudojimo:

Raganos ir (ap)žavèjimai-apkerëjimai ivvairiose Klaipėdos krašto apylinkèse buvo vienur daugiau, kitur mažiau žinomi. Man kartais skaudu prisiminti, kad tai galèjo ivykti tokiame liuteroniškame krašte, kaip Mažojoj Lietuvoj. Paimkime mūsųūkininkus, kurie buvo labai religingi, dievobaimingi, prièmè savo namuose dvasiškus surinkimus ir turejo būti atsparūs visokioms piktujų jègų užgaidoms. ${ }^{59}$

Autorius save tapatina su krikščioniškąja pozicija ir siekia atsiriboti nuo pagoniškos bei nepaaiškinamos patirties. Gydymo būdus, kurie neprieštarauja bažnytiniam požiūriui, autorius bando ivertinti pozityviai, atrasti argumentu, faktu, patirčiu, kuriais galètu paaiškinti arba paneigti gydymo sèkmę ar nesèkmę. Lietuvininkai, tikèję, naudoję ir pasitikëję maginėmis priemonėmis, yra jo gimtojo kaimo žmonès, tačiau ju pasaulèžiūra skiriasi. Autorius brèžia takoskyrą tarp lietuvininkų, tikèjusių magiškais dalykais, ir lietuvininku, besivadovavu- 
sių bažnytinėmis normomis bei racionaliu protu. Autorius konkrečiai nurodo, kad jo kaime buvo penkios šeimos, "tikinčios piktuju dvasiu galiąa “60. J. Skvirblio pasakojimuose akivaizdžios ankstesnių autorių iškeltos religinès prieštaros.

Iš aptartu autorių išsiskiria A. Bruožio surinkti pasakojimai. Juose neatsispindi autoriaus nuomonè, nèra išsakomi jo vertinimai ar pastabos. Pateikiami tik medicininiai faktai, kaip gydyti kokią nors ligą. Kitų autorių darbuose ligu gydymo aprašai sudaro didelę tekstų dalį, o A. Bruožis praktiškai tik juos ir pateikia. Šie tekstukai pasibaigia pasakymu: „taip darant, sako, gelbti“. Visi ligu gydymo aprašai sudèti i skyriu „Liaudies medicina"61. Šiek tiek duomenu apie lietuvininkų socialinius liaudies medicinos aspektus galima rasti kitame skyriuje "Burtai ir prietarai“"62. Pavyzdžiui: „Kad nori žinoti, ar ligonis veik mirs, reik su duona jo koju padus aptrinti ir šuniui pamesti. Jei jis duoną sued, tai ligonis išgis, jei ale neèd, tai mirs. ${ }^{163} \mathrm{Jei}$ iš tiesu A. Bruožis taip užrašinejo pasakojimus, kaip jie pateikiami J. Balio sudarytame rinkinyje, tai šio autoriaus darbas gerokai išsiskiria metodologiniu požiūriu iš jau anksčiau aptartų darbų.

Peržvelgus K. Kapelerio, K. Jurkšaičio, V. Kalvaičio, J. Skvirblio, A. Bruožio darbus matyti, kad Bažnyčios požiūris, kuriam dauguma autorių ir atstovauja, virsta ženklu, žyminčiu ribą tarp savu ir kitu lietuvininku. Ši riba aiškiai brèžiama K. Kapelerio tekstuose - visa, kas prieštarauja Bažnyčios mokymui, paliekama pagonybei ir praeičiai. Ypač aiškiai šią ribą brèžia ir J. Skvirblys. Prieštarą tarp bažnytinès pozicijos bei liaudiškosios tradicijos sprendžia ir K. Jurkšaitis. Da- lykus, kurie primena burtus ir magija, autorius priskiria senoms boboms, t. y. $k i-$ tiems, su kuriais autorius tikrai nesitapatina. Tačiau K. Jurkšaitis bando atrasti vardikli, kuris leistu praplèsti savos kultūros arealą. Jis neapsiriboja tik tuo, ką priima ir atmeta krikščionių bažnyčia. K. Jurkšaitis siekia atskirti žinystę ir žynystę. Tai būtu galima suprasti kaip bandymą atskirti maginị ir mokslini pasaulio pažinimą. V. Kalvaičio nuomonè artimiausia senają pasaulejautą išlaikiusiems lietuvininkams. Autorius bando lietuvininku dvasines patirtis lyginti su Šventajame Rašte aprašytomis patirtimis. Tačiau iš vyskupo negautas palaikymas liudija, kad autorius pats atsiduria už bažnytinès ribos ir praktiškai tampa tuo kitu lietuvininku, nuo kurio atsiriboja K. Kapeleris, K. Jurkšaitis ir J. Skvirblys. Žinoma, vyskupo motyvą neparemti V. Kalvaičio veiklos galëjo nulemti ne tik Bažnyčios pozicija, bet ir politiniai sumetimai. Visiškai nuo vertinimo atriboti A. Bruožio tekstai tarsi iliustruoja tradicinę to meto lietuvininkų liaudies medicinos dalį. Tačiau jie tampa savotiškais artefaktais, atitrauktais nuo gyvenimo realybès, nes juose neatsispindi ir kitos lietuvininku gydymosi tendencijos, atstovaujamos K. Kapelerio, K. Jurkšaičio, J. Skvirblio. Kaip liudija pastarujų autorių darbai, gydymas buvo dinamiškas procesas, reikalaujantis ne tik fizinès adaptacijos, bet galëjęs pareikalauti ir peržengti kultūrines ribas. İdomu, kad nè vienas autorius, kritiškai vertinęs liaudiškas gydymo priemones ir gydytojus, nepateikia jiems priimtino gydymo pavyzdžių. Iš esmės jie patvirtina tą pačią liaudies medicina, persmelktą magijos, kurią ir aprašo A. Bruožis. 


\section{Literatūra ir nuorodos}

1 Jonas Basanaviczius, Medega musu tautiszkai vaistynykystai. Shenandoah, 1898.

${ }^{2}$ Gabrielè Petkevičaitè-Bite, Mатерiаль nо народной медицине литовиевь [Sankt Peterburgas], 1911.

${ }^{3}$ Kazys Grinius et al. Trumpa folkloro dalykams rinkti programa. Vilnius: M. Kuktos spaustuvè, 1910, p. 23-25.

${ }^{4}$ Leonardas Sauka pažymi, kad dr. J. Basanavičiaus iniciatyva buvo pradètas labai reikšmingas burtu, prietaru, liaudies medicinos žinių kaupimo vajus. Jis buvo sèkmingas, pasitelkus, kaip ir kitais kartais, nuoširdžius talkininkus (Leonardas Sauka, Tikèjimu, burtu ir prietaru pasaulis. Juodoji knyga (Jono Basanavičiaus tautosakos biblioteka, t. 12), Kostas Aleksynas (sud.). Vilnius, Lietuvos literatūros ir tautosakos institutas, 2004, p. 7).

${ }^{5}$ Kazys Grigas et al. Kalvaitis Vilius. Mažosios Lietuvos enciklopedija, t. I, 2000, p. 705.

${ }^{6}$ Algirdas Sabaliauskas, Jurkšaits Jurkschat Kristupas. Mažosios Lietuvos enciklopedija, t. I, 2000, p. 676 .

7 Vaclovas Bagdonavičius, Domas Kaunas, Vladas Žukas, Bruožis. Mažosios Lietuvos enciklopedija, t. I, 2000, p. 212. Taip pat prieiga per internetą: http://www.pagegiusvb.lt/index.php/veikla/minetinos-datos/406-mazosios-lietuvos-lietuviurastijos-veikeju-ir-kiti-jubiliejai.html [žiūrèta 201508 12].

8 Vacys Milius, Algirdas Sabaliauskas, Cappeller (Kapeleris) Carl. Mažosios Lietuvos enciklopedija, t. I, 2000, p. 239.

9 Skvirblys Jonas. Mažosios Lietuvos enciklopedija, t. IV, 2009, p. 280.

10 Carl Cappeller, Kaip senéji Lètuvininkai gyveno. Heidelberg: Carl Winter's Universitäts-Buchhandlung, 1904. Prieiga per internetą: http://www. epaveldas.1t/object/recordDescription/LNB/ C1R0000117397 [žiūrèta 201604 12].

11 Jonas Balys (sud.), Iš Mažosios Lietuvos tautosakos (Tautosakos darbai, t. 3). Kaunas: Lietuviu tautosakos archyvas, 1937. Prieiga per internetą: http://www.epaveldas.lt/vbspi/biRecord. do?biRecordId=24563 [žiūrèta 201603 20].

12 Kostas Aleksynas (sud.), Juodoji knyga (Jono Basanavičiaus tautosakos biblioteka, t. 12). Vilnius: Lietuvos literatūros ir tautosakos institutas, 2004.
13 Jonas Skvirblys, Kas tos raganos ir apžavètojai? Lietuvos pajūris, 72, 1988, p. 577-578.

14 Jonas Skvirblys, Mažosios Lietuvos kaimo gydytojai. Lietuvos pajūris, 81, 1988, p. 651-652.

15 Vilius Pèteraitis (sud.), Mažosios Lietuvos garbinga praeitis, liūdna dabartis ir neaiški ateitis. D. 2. Vilnius: Romuna, 2003.

16 Jonas Balys, Iš Mažosios Lietuvos tautosakos, p. 6 .

17 Ten pat, p. 6.

18 Janina Janavičienè, Senujų lietuvininkų liaudies medicina. Lietuvininku kalba; Mažosios Lietuvos tautosaka; Mažosios Lietuvos etnografija: moksliniu konferenciju pranešimai. Kaunas: Kelias, 1994, p. 83-86.

19 Ten pat, p. 83.

${ }^{20}$ Leonardas Sauka, Tikèjimu, burtu ir prietaru pasaulis. Juodoji knyga (Jono Basanavičiaus tautosakos biblioteka, t. 12), Kostas Aleksynas (sud.). Vilnius: Lietuvos literatūros ir tautosakos institutas, 2004, p. 11.

${ }^{21}$ L. Sauka cituoja ištrauką iš Dienknygos, kur moteriške taip atsako V. Kalvaičiui: „Mes turim Dievą liaupsint, o ne tokiais dalykais apsieit.“ Ten pat, p. 11.

22 Ten pat, p. 11.

${ }^{23}$ Rolandas Petkevičius, Nervinių sutrikimu gydymas tradicinemis priemonemis $\mathrm{XX}-\mathrm{XXI}$ a. pr. Aukštaitijoje ir Dzūkijoje". Magistro baigiamasis darbas, Vytauto Didžiojo universitetas, 2011, p. 10-13.

${ }^{24}$ Cappeller, Kaip senèji Lètuvininkai gyveno, p. 35.

25 Ten pat, p. 34.

26 Ten pat, p. 35.

27 Ten pat, p. 35.

28 Ten pat, p. 36

29 Ten pat, p. 37.

${ }^{30}$ Ten pat, p. 37.

${ }^{31}$ Kristupas Jurkšaitis, Pryvieros. Juodoji knyga (Jono Basanavičiaus tautosakos biblioteka, t. 12), Kostas Aleksynas (sud). Vilnius, Lietuvos literatūros ir tautosakos institutas, 2004, p. 40-52.

32 Ten pat, p. 41.

33 Ten pat, p. 50-51.

34 Ten pat, p. 41.

35 Ten pat, p. 51.

36 Ten pat, p. 49.

37 Ten pat, p. 47.

38 Ten pat, p. 48.

39 Ten pat, p. 47-48.

40 Ten pat, p. $47-48$. 
41 Ten pat, p. 48.

42 Ten pat, p. 49.

43 Ten pat, p. 49.

44 Ten pat, p. 49.

45 Ten pat, p. 49-50.

46 Vilius Kalvaitis, Pažiūrai. Juodoji knyga (Jono Basanavičiaus tautosakos biblioteka, t. 12), Kostas Aleksynas (sud.). Vilnius: Lietuvos literatūros ir tautosakos institutas, 2004, p. 53-58.

47 Vilius Kalvaitis, Burtai. Medicina. Kn. Juodoji knyga (Jono Basanavičiaus tautosakos biblioteka, t. 12), Kostas Aleksynas (sud.). Vilnius: Lietuvos literatūros ir tautosakos institutas, 2004, p. 58-96.

48 Vilius Kalvaitis, Laiškas. Juodoji knyga (Jono Basanavičiaus tautosakos biblioteka, t. 12), Kostas Aleksynas (sud.). Vilnius, Lietuvos literatūros ir tautosakos institutas, 2004, p. 96-99.
49 Kalvaitis, Burtai. Medicina, p. 73.

50 Ten pat, p. 91-92.

${ }^{51}$ Kalvaitis, Laiškas, p. 96-99.

52 Skvirblys, Kas tos raganos ir apžavetojai, p. 86-89.

53 Skvirblys, Mažosios Lietuvos kaimo gydytojai, p. 89-91.

54 Ten pat, p. 89.

${ }_{55}$ Ten pat, p. 90.

56 Ten pat, p. 91.

57 Ten pat, p. 91.

58 Ten pat, p. 90.

59 Skvirblys, Kas tos raganos ir apžavetojai, p. 86.

${ }^{60}$ Ten pat, p. 87.

61 Bruožis, Liaudies medicina, p. 28-33.

62 Bruožis, Burtai ir prietarai, p. 9-27.

${ }^{63}$ Ten pat, p. 15.

B. d. 